\title{
TRANSLANGUAGING THROUGH THE LENS OF SOCIOCULTURAL APPROACH : STUDENTS' ATTITUDES AND PRACTICES
}

\author{
Wulandari Santoso \\ Universitas Bunda Mulia, Jakarta \\ Corresponding Email: wsantoso@bundamulia.ac.id
}

Received: $24^{\text {th }}$ of April 2020, Accepted: $18^{\text {th }}$ of May 2020, Published: $18^{\text {th }}$ of June 2020

\begin{abstract}
Recent research developments have an increased focus on the complexity and the dynamic nature of language practices. Translanguaging views multilingual speakers as having one integrated language repertoire which they can use strategically to communicate and involve in the process of meaning-making activities. This research aims to investigate attitudes and practices of translanguaging among English department students in the Language Assessment course at Universitas Bunda Mulia, Jakarta. A series of observations and semi-structured interviews were used to collect data to five students. The data were interpreted using a thematic analysis and critically evaluated using the sociocultural theory of mind. This research revealed that the students translanguaged not only for cognitive functions, but also for creative and critical linguistic practices. Positive attitudes were also demonstrated through the students' active participation in using their full repertoires. Further pedagogical implications in this particular context are also discussed.
\end{abstract}

Keywords: languaging, mediation, sociocultural theory, translanguaging.

\begin{abstract}
Abstrak
Perkembangan penelitian terkini berfokus pada kekompleksitasan dan sifat dinamis dari penggunaan bahasa. Translanguaging memandang penutur multilingual sebagai penutur yang memiliki satu repertoar bahasa yang terintegrasi di mana mereka dapat menggunakan repertoar tersebut untuk berkomunikasi dan terlibat dalam proses pemaknaan. Penelitian ini bertujuan untuk menginvestigasi pandangan dan praktik translanguaging mahasiswa Bahasa Inggris pada mata kuliah Language Assessment di Universitas Bunda Mulia, Jakarta. Observasi dan wawancara semi-terstruktur digunakan untuk mengumpulkan data pada lima orang. Data diinterpretasi menggunakan analisa tematik dan dievaluasi secara kritis menggunakan sociocultural theory of mind. Hasil penelitian menunjukkan bahwa mahasiswa terlibat dalam praktik translanguaging yang tidak hanya bertujuan untuk fungsi kognitif, namun juga untuk praktik kreatif dan kritis dalam berbahasa. Mahasiswa juga memiliki pandangan positif terhadap translanguaging yang ditunjukkan dengan partisipasi aktif dalam menggunakan seluruh repertoar bahasa yang mereka miliki. Implikasi secara pedagogi pada konteks ini juga dibahas lebih lanjut.
\end{abstract}

Kata Kunci: languaging, mediasi, teori sosiokultural, translanguaging.

Copyright (C) 2020 Wulandari Santoso

\section{INTRODUCTION}

In recent years, the idea of discrete languages has been criticised since an immense literature suggests the cross-language relation and the fluid nature of language practices (Creese \& Blackledge, 2010; García, 2009). A number of terms have emerged to better capture the complexity of multilinguals' linguistic repertoires in different contexts (see García \& Wei, 2014). As a result, there has been a confusion about the proliferation of these terms and their usage, questioning whether they are merely part of "sloganization of the post-modern, possibly also post-truth, era" (Wei, 2018, p. 9). 
Nevertheless, these overlapping terms may affirm a shift from monolingualism to plurilinguism in the field of language education.

Despite a growing bulk of terms for academic discourse space, this article adopts the term translanguaging as a theoretical framework. This concept moves away from the view of language as a noun to language as a verb, that is, an ongoing process (Wei, 2011), thus, it goes beyond understanding language as simply 'linguistic'. Translanguaging is defined as the utilisation of one's entire language resources "to gain knowledge, to make sense, to articulate one's thoughts and to communicate about using language" (Wei, 2011, p. 1223). It is important to note that translanguaging is not only about dynamic language practices, but it suggests a unitary linguistic system (Otheguy et al., 2015). When multilingual speakers translanguage, they are deploying an integrated language system comprising structural and lexical resources. In addition, translanguaging is also seen as a political act as it disrupts the so-called named languages which have become a tool for the domination of language minoritized communities (García \& Otheguy, 2020). The named languages are perceived to exclude these communities from economic and socio-political opportunities by legitimating paths only to those who speak what is called the national language (ibid).

When applied in classroom contexts, translanguaging is considered a pedagogical approach which serves as a scaffolding strategy of multilinguals and offers a new viewpoint of conceptualising and understanding multilingualism in this era (Lin \& He, 2017). In this sense, language education is seen as a tool of recognising students' diverse language as a resource to draw upon their existing knowledge and to learn something new.

There has been numerous research on translanguaging practice(S) (e.g. (Duarte, 2019; Garza \& Arreguín-Anderson, 2018; Lin \& He, 2017; Mendoza \& Parba, 2019; (Pavón Vázquez \& Ramos Ordóñez, 2019). Its main discussion in academic settings has touched upon the possible ways of incorporating translanguaging into educational systems in western countries. However, little research has been done on translanguaging practices in multilingual communities, particularly in the east (García \& Wei, 2014).

The purpose of this study is to investigate English department students' attitudes and practices of translanguaging in a teaching course, named Language Assessment, in a private university in Jakarta. In this course, the students are required to learn content(S) related to English language education and engage in cognitively complex tasks while using English as the (A) medium of instruction. The data was then interpreted qualitatively using the key concepts that are central to a Vygotskian sociocultural theory. 
This study aims to answer the following research question: what are the English department students' attitudes of translanguaging and their translanguaging practices in learning content in the Language Assessment course?

\section{Why translanguaging?}

The term translanguaging was originally coined by Williams (1994) as cited in García and Wei (2014) to refer to a pedagogical language practice in Welsh revitalisation programmes in which the students are required to read in Welsh and write in English or vice versa. Instead of viewing this practice negatively, Williams suggests that it helps both teachers and students maximise their linguistic resources for knowledge construction and problem-solving tasks. Since then, the term translanguaging has been conceptualised to capture the complex language practices of multilingual individuals and the pedagogical approaches that use integrated language repertoires (see Blackedge \& Creese, 2010; Canagarajah, 2011a; Garcia, 2009; Wei, 2011).

Some scholars have defined translanguaging slightly different. While Baker (2011) and Lewis et al. (2012) emphasise on the utilisation of two languages in the process of meaning-making and gaining knowledge, others have recognised the complexity of language exchanges among individuals and communities (García \& Wei, 2014). For example, Canagarajah (2011b, p. 401) argues that translanguaging is "the ability of multilingual speakers to shuttle between languages, treating the diverse languages that form their repertoire as an integrated system". In this view, translanguaging goes beyond the concept of shifting between two languages, which encompasses the idea of separate linguistic systems (Otheguy et al., 2015) which may impose language separation by "othering the languages of those who spoke them within the nation" (García \& Wei, 2014, p. 54).

Elsewhere, Garcia (2009) states that translanguaging refers to the speaker's construction and complex interrelated discursive practices that are fully utilised to involve in and make sense of the multilingual worlds. In other words, the speaker's language practices are not perceived as the use of a fixed entity (Blommaert, 2014), which bounds to an established nation (Otheguy et al., 2015). The socio-politically defined boundaries of named languages are deemed incompatible particularly in multilingual settings as it does not reflect the actual language use in the society which is constantly and dynamically changing in the process of interactions (García \& Wei, 2014).

Following some proponents of translanguaging (e.g. Garcia, 2009; García \& Wei, 2014; Zein, 2018), this study views translanguaging as deploying one's full language resources freely without regard for the linguistic boundaries. This deconstructed view of language use liberates multilingual speakers from language frontiers as it involves a dynamic speech repertoire that overlaps between socio-politically defined languages that the speakers of those languages utilise flexibly and creatively to engage in meaning-making discursive modes. As Wei (2011) argues, translanguaging requires the 
ability to select between adhering and flouting the rules of language use and to use available resources systematically for purposes that go beyond the alternation between language systems and the exchange of information. Therefore, translanguaging is seen as transformative because it is an ongoing process of creating a social space, called a translanguaging space, which allows multilinguals to embrace their individual experience, identities, belief, and ideology into one integrated performance (Wei, 2011).

Despite the importance of the refined conceptual language practice, the application of translanguaging in classroom contexts is still questionable (Canagarajah, 2011a; Rasman, 2018). Moreover, many schools tend to limit translanguaging practice among learners as they are still in favour of monolingual teaching (Otheguy et al., 2015). When it comes to pedagogical practices, other factors such as, to what extent translanguaging space should be provided and how translanguaging may assist learning need to be considered (Palmer et al., 2014). Nevertheless, it is important to note that translanguaging offers an epistemological alternative which enables learners to use and expand their single linguistic resources and abilities, resulting in the appreciation of their entire repertoires.

\section{Sociocultural theory}

Vygotskian perspectives on learning has mostly influenced mainstream education for some decades. Sociocultural theory suggests that knowledge is acquired interpersonally, thus, engaging socially in groups is a vital part of learning. As Lantolf and Throne (2006) argue, learners' developmental processes occur through interactions and participation in sociocultural settings. Hence, learning is seen as a social practice that requires leaners to build relationships with others and the world.

In addition to using language as communicative functions, Vygotsky also views language as a psychological tool that mediates the mind, that is, "it functions to focus attention of, to develop, to organize, to control - one's own higher mental functions" (Swain \& Lapkin, 2013, p. 105). In other words, leaners use language to take control of their mental processes and to construct ideas they are trying to convey, to create affect, and to solve problems (Lantolf \& Throne, 2006).

In the sociocultural perspective, knowledge can only be constructed through a dialogic space in which learners' communicative and sociocultural repertoires are brought together (Wong, 2005). Hence, arguably, sociocultural theory also supports translanguaging practice to foster learning. Early research revealed that the use of students' home languages was beneficial for numerous purposes. For example, Cohen (1994) found that students used their home languages in their cognitive processing, for instance, to clarify difficult concepts and to understand the content of the task. Similarly, drawing on sociocultural perspectives, Swain \& Lapkin (2000) found that students used their home languages to assist them to gain understanding in accomplishing tasks, to help them focus their attention on 
linguistic features, and to establish interpersonal relationships. In their research, Antón \& Dicamilla (1999) found that students made use of their home languages to (1) provide their peers with scaffolded help which was crucial in making tasks manageable, (2) maintain intersubjectivity, and (3) externalise students' inner speech, speech directed to the self to direct one's mental activity.

\section{Languaging and its implication on translanguaging}

In his early work on languaging, Becker (1988) states that language is not merely a code or a set of rules, rather he prefers the term languaging to describe an ongoing process of our interactions with the world. As language has been reconceptualised as social practices, the term languaging has been widely adopted by many sociolinguists (e.g. Canagarajah, 2007; Makoni \& Pennycook, 2007) to refer to the simultaneous process of interactive meaning-making. In this view, language is seen as an essential part of interaction and construction of meaning, thus, it is not a structure but something that we do as part of social life.

In addition to the social aspect, the cognitive side of language practices is also considered. In relation to the cognitive aspect, Swain (2006, p. 96) defines languaging as "a dynamic, never-ending process of using language to make meaning". She further argues that languaging is "a process of... shaping knowledge and experience through language" (Swain, 2006, p. 97). Thus, language is used to organise and regulate our thinking. The activity of languaging functions as a tool to mediate cognitively complex thoughts such as planning, problem solving, and decision making (Brooks et al., 2010).

In a more recent study, (Wei, 2017) states that languaging has been the bedrock notion of the term translanguaging, while other scholars have proposed this concept based on the actual language practice (Baker, 2011; William, 1994 as cited in Garcia \& Wei, 2014). She then advocates some arguments emphasising that the addition of the Trans to Languaging not only means proposing a term to better capture the dynamic practices of multilingual speakers regardless the defined language boundaries, but also highlights the process of meaning-making and knowledge construction which requires the utilisation of various cognitive, semiotic, and modal resources (Wei, 2017). In this sense, the thought processes of multilingual language users occur with reference to their 'other' languages. It may not make any sense to assume that they think in a separate linguistic system, rather they use their unique idiolect which transcend the boundaries of socio-politically defined language (Otheguy et al., 2015; Wei, 2018)

The two key concepts of languaging, e.g. private speech and collaborative dialogue, are prevalent among learners in constructing meaning. While the former means speech that is directed to oneself and is shortened from what one might be saying when an interlocutor is present (Swain \& Lapkin, 2000, 2013), the latter refers to a dialogue where two or more speakers are involved in 
knowledge building and problem solving (Swain \& Lapkin, 2000, 2013). Both forms of languaging enable learners to articulate their thinking and to understand complex concepts as they serve as a mediating tool. Interestingly, some studies (e.g. Garcia, 2011; Lin \& Wu, 2015) revealed that the students translanguaged during their private speech and collaborative dialogue. In Garcia's (2011) research on young learners in a two-way dual language programme, the students activated their full linguistic repertoire to learn and interact with their peers and their teachers. Lin \& Wu (2015) investigating a Grade 7 EMI (English as a Medium of Instruction) science lesson found that the students translanguaged to understand difficult concepts during the scientific discussion, leading to the active co-construction of knowledge. Thus, it could be argued that translanguaging allows learners to build their thinking and become more knowledgeable as they develop their language practices for accomplishing cognitively complex tasks.

\section{Previous studies}

Numerous research has offered evidence that students' linguistic resources have numerous functions in terms of psychological, cognitive, and pedagogical aspects (Lee \& Macaro, 2013; Moore, 2013; Turnbull, 2001). Most research has mostly adopted ethnography approaches and observations to identify translanguaging practice in the classroom (e.g. Duarte, 2019; Garza \& Arreguín-Anderson, 2018; Lin \& He, 2017; Mendoza \& Parba, 2019; Pavón Vázquez \& Ramos Ordóñez, 2019). For example, Duarte's (2019) research on mainstream education showed that translanguaging played roles in helping students learn through collaborative talk during cognitively demanding tasks and in scaffolding meaning through interaction to solve tasks. Similarly, Lin \& He (2017) investigating the roles of translanguaging in CLIL classrooms in Hong Kong found that students' home language was used to negotiate meaning, give encouragement, and building rapport. Interestingly, this study also revealed that students used their full repertoires for identity affirmation.

Furthermore, some research has shown an interest in understanding the participants' views about language practice in the classroom. Similar to Wu's (2006) research, Li and Wu (2009) found that despite the monolingual policy in schools, learners' of Chinese in the UK reported having creative language practices. In her study, Wang (2019) using multiple instruments found that over a half of the students in China's universities favoured multilingual instructions where they could utilise their integrated linguistic repertoires for meaning negotiation and peer-support, while the teachers had a nuanced attitude towards translanguaging. Although they acknowledged the importance of translanguaging for practical reasons, they wished they could add more languages to their repertoires. In the observation, translanguaging practices served several functions such as, providing cognitive and metalinguistic scaffolding, interpreting cultural meaning, and engaging in teacher-student relationships. Carstens (2016) examining students' views on translanguaging in learning content in 
South Africa contexts. The questionnaire results revealed that students had positive attitudes of using their own language repertoires and experienced both cognitive and affective benefits such as, simplifying complex concepts, helping students express conceptual content, creating a comfortable classroom atmosphere, and promoting collaboration.

\section{METHOD}

\section{Research design}

This research utilised the case study methodology, referring to "the study of the particularity and complexity of a single case" Stake (1995, p. xi). It requires an in-depth investigation on phenomena in real life contexts (Simons, 2009). In this research, the case study is a methodology which attempts to capture the complexity of a case in real-life situations. This research also utilised the qualitative method since it facilitates thorough explorations of participants' views and practices (Creswell, 2014; Punch, 2009).

The case study is considered appropriate to be used in this research as it aims to gain comprehensive understanding and to interpret data particularly within the research context. Despite its lack of generalisability which is not necessarily the objective of this research, the case study is deemed suitable to understand the case with its complexity within the given context (Simons, 2009; Punch, 2009).

\section{Population and sample}

Convenience sampling was used in this research as it involves drawing samples that are willing to take part in the study (Dornyei, 2007). The participants of this study were limited to the English department students who are taking the Language Assessment course in the sixth semester. This course was compulsory and specifically designed for the students who are taking the English education major at Universitas Bunda Mulia, Jakarta. The total students who are taking this course was twelve, and five of them were asked to participate in this research. The selection of the participants were based on their bi/multilingual backgrounds. The limited sampling and scope of the study may affect the implication of this research perhaps making it not applicable in many learning contexts.

\section{Data collection techniques and tools}

A series of observations to five students were conducted to know the activities of individuals in their natural settings (Creswell, 2014). Classroom observations was considered suitable for collecting data related to students' language practices in naturalistic settings. The classroom was audio-recorded. Each recorded class lasted for 70 minutes. In total around 220 minutes of classroom teaching were gathered in this research. It should be acknowledged that the presence of the observer in the classroom may affect the situation under observations. Thus, non-participant observations, in which the researcher observes participants without actively participating, were chosen to reduce the possible effect where the participants may modify their behaviour (ibid). 
Following observations, semi-structured interviews to five students were used in order to collect the participants' experiences, opinons, and feelings about translanguaging practices. This research instrument was expected to generate the narration of their experiences and unanticipated responses (Gray, 2014; Punch, 2009). Each participant was interviewed for 30 minutes, and the data was transcribed verbatim.

\section{Data analysis techniques}

The framework for thematic analysis proposed by Robson (2013) was used in this study. The data were transcribed and re-read in order to understand common patterns. They were classified into initial codes by giving similar codes to similar extracts. Based on the codes, themes were identified by organising codes into potential themes. Afterwards, main themes were created along with sub-themes. The data were then interpreted by noticing patterns, ideas, and associations.

In addition, the key constructs of sociocultural theory are also used as a reference for critically interpreting the qualitative data. The sociocultural theory of mind arguably provides an effective framework as it affirms the mediating role of other languages with particular attention to cognitively complex tasks.

\section{FINDINGS AND DISCUSSION}

The findings of this study are presented based on the themes and are linked to the key concepts of the sociocultural theory that are reflected in the students' language choices. Pseudonyms are also used to protect the participants' identities.

\section{Scaffolding and Mediation}

In this part, translanguaging is perceived as a tool to scaffold students in order to comprehend complex concepts (Lin \& He, 2017). The extracts in this section are parts of conversations among three students named Bobby, Dani, and Lia.

The following extract (Extract 1) is a conversation during group discussion activities in the Language Assessment course. They were discussing the assessment criteria used in the speaking activities.

\section{Extract 1}

Bo (1): Bedanya pronunciation sama fluency?

<The difference between pronunciation and fluency?>

Li (2): They are different. Fluency itu kelancaran ngomongnya, kalau pronounciation itu ya cara dia ngomongnya.

$<$ Fluency is the flow of utterances, while pronunciation is how the speaker talks>

Bo (3): The words?

Li (4): Cara dia menyebutkannya. 
$<$ It's how the speaker say the words $>$

Kalau fluency itu lancar atau nggak.

$<$ While fluency is whether the utterances are fluent or not>

Da (5): Apakah terbata-bata.

$<$ Whether the utterances are haltingly said $>$

Bo (6): I see.

These lines indicate that the two students tried to scaffold Bobby who did not understand the distinction between fluency and pronunciation. In line (6), Bobby showed that he understood the difference by saying 'I see'. This would hardly be possible if the students did not utilise their full repertoires of English and Indonesian. Furthermore, the task could have not been completed if the students restrained themselves to use English only in the classroom.

Extract 2 demonstrates another example of how scaffolding through translanguaging may also result in the creativity of using languages. These conversations between Anna and Ella were recorded during the task completion of making assessment criteria.

\section{Extract 2}

An (1): Tadi apa?

$<$ What was that?>

Daily activities. Language expression nya apa?

$<$ What are the language expressions?>

El (2): I never.

An (3): I never. I sometimes. Dah gitu-gitu aja.

$<$ That's it $>$

El (4): Iya pokoknya pakai yang degree of ini.

$<$ Yes, use the degree of this $>$

Daily activities nya apa?

$<$ What are the daily activities?>

Misalnya, washing the dishes.

$<$ For example, washing the dishes>

An (5): Berarti tadi description-nya fluency, accuracy, pronun.

<So, the descriptions are fluency, accuracy, and pronun>

El (6): Change the accuracy into this one ya? Soalnya sama kan accuracy sama pronun?

<Because accuracy and pronun are the same, right?>

An (7): Accuracy itu buat grammar nya.

$<$ Accuracy is for the grammar> 
Pronunciation itu cara dia ngomongnya.

<Pronunciation is the way the speaker talks>

Jadi lo mau dia ada simple present tense nggak?

$<$ So, do you want to use the simple present tense? >

Kalau memang nggak ada, ya jangan.

$<$ If no, then do not use it $>$

Do not use the accuracy. Tapi kalau misalkan lo mau assess the simple present tense, ya you need the accuracy.

<But, if you want to assess the simple present tense, ya you need the accuracy>

The results of this study are similar to some research (e.g. Duarte, 2019; Lin \& He, 2017; Pavón Vázquez \& Ramos Ordóñez, 2019) which revealed that students involved in the translanguaging practice during problem-solving tasks. Since English is not the home language of the students and they might find difficulties when the content of the lesson is difficult for them, the use of students' familiar languages may activate their prior knowledge which assist them to comprehend cognitively demanding materials (Lin \& He, 2017). As Swain \& Lapkin (2013, p. 113) argue, when the "going gets tough" in the target language, students' home languages are an important cognitive and mediating tool to help students organise their thoughts and focus attention during classroom interactions. As seen in Extract 1, the students here provide an illustrative case of how students language (as a verb) in which more expert learners helps another person to go beyond what they can do alone in conceptual understanding in order to mediate their higher mental functions.

In Extract 2, it could be argued that not only does the conversation demonstrate the translanguaging practice to deal with cognitive challenges, it also may reflect, what García \& Wei (2014) calls, creative translanguaging. This term refers to the creative process and the flexibility of language use of bi/multilingual students in order to develop new language practices (ibid). We can see in Extract 2, the students somehow shortened the word 'pronunciation' into 'pronun'. Intriguingly, the students seemed to have a shared understanding of what it meant by 'pronun'. In the conversation, although they pronounced the word as 'prō-, naün' (as in 'pronoun'), it could be argued that each of them did not mistakenly understand the word as 'pronoun', which has a different meaning. It is particularly interesting that the students seemed to flexibly use the language without any hesitation in flouting the rules of language use. During the interview, Anna said:

“Saya nggak tau kenapa saya pakai kata 'pronun' to refer to pronunciation. <I don't know why I used the word 'pronun' to refer to pronunciation> I think it's just the way I express the word. It just came out naturally". 
Meanwhile, Ella added:

"I think it's quite interesting that we all understood what we meant by 'pronun'. Buat aku sih, itu untuk nyingkat kata 'pronunciation'. <For me, it's just a short version of the word 'pronunciation' > and it makes us easier to pronounce the word."

This research result is in accordance with (Palmer et al., 2014) finding that translanguaging pedagogies may create spaces for students to take risks in expressing themselves. This phenomenon is also in line with Wei's (2011) argument that translanguaging practices demonstrate both creativity and criticality. While the former refers to the ability to break boundaries and norms of linguistic behaviour, the latter entails the ability to use evidence to problematize and articulate views. Thus, these dynamic practices help the students experiment and maximise their linguistic resources in order to solve problems and construct knowledge.

In addition, it could be argued that Extracts 1 and 2 may also show how the use of full linguistic repertoires during scaffolding, where a more competent learner helps another person to finish a task he/she cannot do alone (Swain \& Lapkin, 2013), allows the students

to work within their Zone of Proximal Development (ZPD). In this case, the ZPD that the students was enacted was part of the process of internalising complex conceptual understanding and completing tasks.

\section{2. (Trans)languaging: collaborative dialogue and private speech}

This research revealed that the students utilised their home languages during collaborative dialogue and private speech. These two main concepts of the sociocultural theory are deemed essential in controlling the mental processes and facilitating the formulation of ideas (Lantolf \& Throne, 2006).

Extract 3 is an example of collaborative dialogue among the students. The conversation shows the process of negotiation where the students had to make decisions about the descriptions of the assessment criteria.

\section{$\underline{\text { Extract } 3}$}

Li (1): Eh, tulis deskripsinya kan?

$<$ Eh, write the descriptions, right?>

An (2): Yes. Misalnya excellent itu students speak bla bla bla...

$<$ Yes. For example, excellent means students speak bla bla bla... >

Li (3): Tuh kan.

<See?>

Nah, ini ada berapa?

$<$ Nah, how many are they?>

Satu, dua, tiga, empat, lima. 
$<$ One, two, three, four, five>

Ada dua lima...

$<$ There are twenty five... $>$

Sedikit terbata-bata, terbata-batanya sedikit.

<With little hesitation, with little hesitation>

Eh... pakai bahasa Indonesia dulu, lah

$<$ Eh...use Bahasa Indonesia first, lah $>$

Tidak terbata-bata atau hanya sedikit.

$<$ With no hesitation or with little hesitation>

Bo (5): kurang lancar?

<Less fluent?>

Li (6): kurang lancar itu kayanya.

<Less fluent, maybe>

Bo (7): Less fluent in terms of?

Li (8): Tunggu.

$<$ Wait>

Ada terbata-bata.

$<$ With hesitation>

Sedikit terbata-bata.

$<$ With little hesitation>

Hanya sedikit sekali, gitu?

<Only very few?>

'Sedikit sekali' itu mungkin harus diliat dari, misalkan, gimana?

<'Very few' should be seen from, for example, how?>

Mungkin terbata-batanya hanya sekali dua kali gitu?

<Maybe only one or two hesitations?>

Emang bisa diukur begitu ya?

$<$ Can hesitation be measured?>

Bo (9): Jangan general begitu.

$<$ Do not be general>

Namanya juga deskripsi.

<They are descriptions>

In-depth, dong. <In-depth, dong>

Tidak terbata-bata sama sekali, gitu? 
<You mean with no hesitation?>

Apa bahasa Inggris nya?

<What is the meaning of the words in English?>

Da (10): No hesitation?

Li (11): Ya udah deh.

$<$ Okay>

Jadi, students speak without hesitation?

<So, students speak without hesitation?>

Bo (12): Ya oke.

$<$ Yes, OK>

During the interviews, Lia stated that it was difficult for her to discuss the content in English:

"Susah y a ngomong pakai Bahasa Inggris, especially about unfamiliar vocabulary. < It's very hard for us to speak in English, especially about unfamiliar vocabulary> That's why I said it's better for us to discuss in Bahasa first. Setelah tau jawabannya, baru kita tulis pakai Bahasa Inggris." <After we figured out the answers, we could just write them down in English.>

Dani also said:

"I also prefer using Bahasa during group discussion. Well, we all understand Bahasa better than English, so I think the discussion would be easier and more effective in Bahasa."

Bobby added:

"I think it (using one's full repertoires) makes me comfortable to interact with the other students. Pakai Inggris terus bikin pusing. " <Using English all the time makes me dizzy>

The discussion among the students shows that in the interaction, the students used their integrated linguistic repertoires to negotiate and complete tasks which are probably designed to be slightly beyond the students' level of competence, thus, collaborate efforts among the students are required to achieve the assigned goal ( $\mathrm{Wu}, 2018)$. The finding of this study revealing that the students translanguaged in the collaborative dialogue is similar to recent studies (e.g. Duarte, 2019; Pavón Vázquez \& Ramos Ordóñez, 2019). This research also reflects comparable results with prior research (e.g. Carstens, 2016; Wang, 2019) which revealed that using their full language resources was favourable for practical purposes such as, simplifying difficult words, engaging in collaborative work, and building rapport. In this research, language-mediated collaboration has helped the students organise their thoughts during the negotiation of meaning and knowledge building. As Antón \& Dicamilla (1999) argue, during the collaborative dialogue, students can develop strategies to make tasks manageable and help them focus on the task accomplishment. In Extract 3, the students came to understand not only the meaning of 'tidak terbata-bata', but also the assessment criteria that they 
needed to put in the scoring rubric. Their use of Bahasa Indonesia was necessary to mediate their understanding (see Line $3 \&$ Line 9) and to let them internalise the difficult concept and the aspect of the word meaning. As a result, the students found the solution in English through the collaborative dialogue mediated in Bahasa Indonesia.

In addition to the collaborative dialogue, another way to regulate students' mental functioning is through private speech (Lantolf \& Throne, 2006). The following extract (Extract 4) is an instance of private speech by one of the students:

\section{Extract 4}

Da (1): Accuracy itu apa? <What is accuracy?> .. Tulisannya accuracy in speaking? <The writing will be accuracy in speaking?> Apa tuh artinya. <What does it (the accuracy) mean?> Oh, refers to how to correct learners' use of the language system.

This result is in line with some research (e.g. Garcia, 2011; Lin \& Wu, 2015) revealing that students translanguaged during the private speech. Swain \& Lapkin (2013) state that the use of private speech may indicate that students attempt to regain self-regulation. In other words, it mediates one's own thinking. Lantolf and Throne (2006) emphasise that such utterances during the private speech help students focus their attention on what requires to be accomplished and how to accomplish it. As seen in Extract 4, the student used some abbreviated forms to understand the meaning of accuracy. For example, the word "Oh" implies that the student has discovered what he was searching for. Also, he used his full repertoires as a mediating tool during the process of formulating ideas as he prepared to produce an end product in the target language. A study conducted by Chi et al. (1994) found that students who self-explained displayed a deeper understanding of the content they are learning. Thus, it could be argued that using students' integrated linguistic systems is an essential part of the learning process.

To sum up, this study found similar results to some prior research that the participants were engaged in the translanguaging practice in the Language Assessment course for numerous purposes, for example, to assist their peers (e.g. Lin \& He, 2017), to mediate their thinking during problem-solving tasks (e.g. Duarte, 2019; Lin \& He, 2017; Pavón Vázquez \& Ramos Ordóñez, 2019), to express creativity and criticality (García \& Wei, 2014), and to get involved in collaborative dialogue and private speech (e.g. Duarte, 2019; Pavón Vázquez \& Ramos Ordóñez, 2019). These findings challenge the monolingual principles and value translanguaging as a pedagogical tool to the use of one's full language repertoires. It could be argued that the results of this study may reject the traditional view that regards language as separated linguistic systems. As García \& Wei (2014) argue, translanguaging is naturally occuring speech in which bi/multilinguals utilise their bi/multicultural resources. Therefore, the dynamic nature of language practices should be maximised to break communication 
barriers, to encourage creative thinking, to enhance learning motivation, and to affirm learner bi/multilingual identities (Lin \& He, 2017).

It should be acknowledged that it is not an easy task to apply translanguaging practices in some contexts where the monolingual bias is still deeply rooted in both teachers' and students' beliefs (Rasman, 2018). Nevertheless, the fact that the pedagogical importance of translanguaging is increasingly promoted has reconceptualised classroom pedagogies, resulting in the demand of teaching practitioners to develop their teaching and research quality. Canagarajah (2011a) states that a lack of explicit taxonomic structures within transanguaging pedagogies may pose challenges for teachers to realise translanguaging in language classrooms. Following Wang (2019), it is advisable that future research in translanguaging may shift its focus from proposing theoretical foundations of translanguaging to concrete and practical teaching and learning techniques which incorporate translanguaging practices.

\section{CONCLUSION}

This study has shown how the translanguaging practice plays roles in students' learning in the context of a university level in Jakarta, Indonesia. The findings of this research revealed that the students were involved in the translanguaging practice in the Language Assessment course. They used their integrated repertoires for a number of purposes such as, scaffold their understanding of difficult concepts, stimulate their creativity and criticality in using the languages, and engage in collaborative dialogues and private speech. In addition, the students also believed that such practices were essential during the negotiation of meaning and knowledge building as utilising their full linguistic systems allow them to process and mediate their own thinking while they prepare the outcome in the target language.

These research results may suggest that there is a room for the incorporation of students' dynamic practices in using the languages they know in this particular context. The use of students' language resources does not inhibit language learning as assumed by the widespread belief of language separation in education. In contrast, translanguaging could help students add their own repertoires and involve in creative practices.

This study has some limitations that should be taken into account. Due its small scale, the research results may not reflect and students' attitudes and practices of translanguaging across Indonesia. Yet, this case study may be transferable to other contexts considering the usability of findings. Based on the research results, further studies may discuss teachers' and students' interactions focusing on their translanguaging practice in content classrooms. 


\section{REFERENCES}

Antón, M., \& Dicamilla, F. J. (1999). Socio-cognitive functions of L1 collaborative interaction in the L2 classroom. Modern Language Journal, 83(2), 233-247. https://doi.org/10.1111/00267902.00018

Baker, C. (2011). Foundations of Bilingual Education and Bilingualism (Fitfth Edition). Clevedon: Multilingual Matters.

Becker, A. L. (1988). Language in particular: A lecture. In D. Tannen, Linguistics in context (pp. 1735). Norwood, NJ: Ablex.

Creswell, J.W. (2014). Research design: Qualitative, quantitative, and mixed methods approaches (Fourth Edition). London: Sage.

Blackledge, A. \& Creese, A. (2010). Multilingualism: A Critical perspective. London: Continuum.

Blommaert, J. (2014). From mobility to complexity in sociolinguistics theory and method. UCoupland, Nik (ur.). Sociolinguistics: Theoretical debates, 242-262.

Brooks L., Swain, M., Lapkin S., \& Knouzi, I. (2010). Mediating between scientific and spontaneous concepts through languaging. Language Awareness, 19(2), 89-110.

Canagarajah, S. (2007). The ecology of global English. International Multilingual Research Journal, $1(2), 89-100$.

Canagarajah, S. (2011a). Codemeshing in academic writing: Identifying teachable strategies of translanguaging. The Modern Language Journal, 95, 401-417.

Canagarajah, S. (2011b). Translanguaging in the classroom: Emerging issues for research and pedagogy. In L. Wei, Applied linguistics review volume 2 (pp. 1-27). Berlin, Germany: De Gruyter Mouton.

Carstens, A. (2016). Translanguaging as a vehicle for L2 acquisition and L1 development: students' perceptions. Language Matters, 47(2), 203-222. https://doi.org/10.1080/10228195.2016.1153135

Chi, M.T.H., Leeuw, N.D., Chiu, M., \& Lavancher, C. (1994). Eliciting self-explanations improves understanding. Cognitive Science, 18, 439-477.

Cohen, A. 1994: The language used to perform cognitive operations during full-immersion maths tasks. Language Testing 11: 171-95. 
Creese, A., \& Blackledge, A. (2010). Translanguaging in the bilingual classroom: A pedagogy for learning and teaching? Modern Language Journal. https://doi.org/10.1111/j.15404781.2009.00986.x

Dornyei, Z. (2007). Research methods in applied linguistics. New York, Oxford University Press.

Duarte, J. (2019). Translanguaging in mainstream education: a sociocultural approach. International Journal of Bilingual Education and Bilingualism, 22(2), 150-164. https://doi.org/10.1080/13670050.2016.1231774

García, O. (2009). Bilingual education in the 21st century: A global perspective. Malden, MA and Oxford: Wiley/Blackwell.

Garcia, O. (with Makar, C., Starcevic, M. and Terry, A.) (2011). Translanguaging of latino kindergarteners. In K. Potowski and J. Rothman, Bilingual youth: Spanish in English speaking societies (pp. 33-55). Amsterdam: John Benjamins.

García, O., \& Otheguy, R. (2020). Plurilingualism and translanguaging: commonalities and divergences. International Journal of Bilingual Education and Bilingualism, 23(1), 17-35. https://doi.org/10.1080/13670050.2019.1598932

García, O., \& Wei, L. (2013). Translanguaging: Language, bilingualism and education. In Translanguaging: Language, Bilingualism and Education. https://doi.org/10.1057/9781137385765

Garza, E., \& Arreguín-Anderson, M. G. (2018). Translanguaging: Developing scientific inquiry in a dual language classroom. Bilingual Research Journal, 41(2), 101-116. https://doi.org/10.1080/15235882.2018.1451790

Gray, D. (2014). Doing research in the real world (Third Edition). London: Sage.

Lantolf, J.P., \& Thorne, S.L. (2006). Sociocultural theory and the genesis of second language development. Oxford: Oxford University Press.

Lewis, G., Jones, B., \& Baker, C. (2012). Translanguaging: Developing its conceptualisation and contextualisation. Educational Research and Evaluation, 18(7), 655-670.

Li, W., \& Wu. C.J. (2009). Polite Chinese children revisited: Creativity and the use of codeswitching in the Chinese complementary school classroom. International Journal of Bilingual Education and Bilingualism, 12(2), 193-211. 
Lin, A. M. Y., \& He, P. (2017). Translanguaging as Dynamic Activity Flows in CLIL Classrooms. Journal of Language, Identity and Education, 16(4), 228-244. https://doi.org/10.1080/15348458.2017.1328283

Lin, A. M. Y., \& Wu, Y. (2015). 'May I speak Cantonese?' - Co-constructing a scientific proof in an EFL junior secondary science classroom. International Journal of Bilingual Education and Bilingualism, 18(3), 289-305. https://doi.org/10.1080/13670050.2014.988113

Makoni, S., \& Pennycook, A. (2007). Disinventing and reconstituting languages. Clevedon, UK: Multilingual Matters).

Mendoza, A., \& Parba, J. (2019). Thwarted: relinquishing educator beliefs to understand translanguaging from learners' point of view. International Journal of Multilingualism, 16(3), 270-285. https://doi.org/10.1080/14790718.2018.1441843

Moore, P. J. (2013). An emergent perspective on the use of the first language in the english-as-aforeign-language classroom. Modern Language Journal, 97(1), 239-253. https://doi.org/10.1111/j.1540-4781.2013.01429.x

Otheguy, R., García, O., \& Reid, W. (2015). Clarifying translanguaging and deconstructing named languages: A perspective from linguistics. Applied Linguistics Review, 6(3), 281-307. https://doi.org/10.1515/applirev-2015-0014

Palmer, D. K., Martínez, R. A., Mateus, S. G., \& Henderson, K. (2014). Reframing the debate on language separation: Toward a vision for translanguaging pedagogies in the dual language classroom. Modern Language Journal. https://doi.org/10.1111/modl.12121

Pavón Vázquez, V., \& Ramos Ordóñez, M. del C. (2019). Describing the use of the L1 in CLIL: an analysis of L1 communication strategies in classroom interaction. International Journal of Bilingual Education and Bilingualism, 22(1), 35-48. https://doi.org/10.1080/13670050.2018.1511681

Punch, K.F. (2009). Introduction to research methods in education. London: Sage.

Rasman. (2018). To translanguage or not to translanguage? The multilingual practice in an indonesian EFL classroom. Indonesian Journal of Applied Linguistics, 7(3), 687-694. https://doi.org/10.17509/ijal.v7i3.9819

Robson, C. (1993). Real World Research (Third Edition). Chicester: John Wiley \& Sons.

Simons, H. (2009). Case study research in practice. London: Sage. 
Stake, R.E. (1995). The art of case study research. Thousand Oaks, California: Sage.

Swain, M. (2006). Languaging, agency and collaboration in advanced second language proficiency. In H. Byrnes, Advanced language learning: The contribution of Halliday and Vygotsky (pp. 95108). London: Continuum.

Swain, M., \& Lapkin, S. (2000). Task-based second language learning: The uses of the first language. Language Teaching Research, 4(3), 251-274. https://doi.org/10.1177/136216880000400304

Swain, M., \& Lapkin, S. (2013). A Vygotskian sociocultural perspective on immersion education: The L1/L2 debate. Journal of Immersion and Content-Based Language Education, 1(1), 101-129. https://doi.org/10.1075/jicb.1.1.05swa

Turnbull, M. (2001). “There Is a Role for the L1 in Second and Foreign Language Teaching, but....”. Canadian Modern Language Review/La Revue canadienne des langues vivantes, 57(4), pp. 531540.

Wang, D. (2019). Translanguaging in Chinese foreign language classrooms: students and teachers' attitudes and practices. International Journal of Bilingual Education and Bilingualism, 22(2), 138-149. https://doi.org/10.1080/13670050.2016.1231773

Wei, L. (2011). Moment Analysis and translanguaging space: Discursive construction of identities by multilingual Chinese youth in Britain. Journal of Pragmatics, 43(5), 1222-1235. https://doi.org/10.1016/j.pragma.2010.07.035

Wei, L. (2018). Translanguaging as a Practical Theory of Language. Applied Linguistics, 39(1), 9-30. https://doi.org/10.1093/applin/amx039

Wong, S. (2005). Dialogic approaches to TESOL: Where the ginkgo tree grows. New York: Routledge.

Wu, C. J. (2006). Look who's talking: Language choices and culture of learning in UK Chinese classrooms. Language and Education, 20(1), 62-75.

Wu, W. (2018). A Vygotskyan sociocultural perspective on the role of L1 in target language learning. Cambridge Open-Review Educational Research e-Journal, 5, 87-103.

Zein, S. (2018). Translanguaging in the EYL classroom as a metadiscursive practice: Preparing prospective teachers. In S. Zein, \& R. Stroupe, English language teacher preparation in Asia: Policy, research and practice (pp. 47-62). New York: Routledge. 